\title{
Conjunction of Inorganic and Organic Nutrients in Combination with Biofertilizers on Economic Analysis of Tissue Culture Banana cv. Grand Naine (AAA)
}

\author{
S. Firoz Hussain ${ }^{1 *}$, Lakshminarayana $\operatorname{Reddy}^{1}$ and Venkata Ramudu ${ }^{2}$ \\ ${ }^{1}$ Dr YSRHU, Venkataramannagudem, Andhra Pradesh, India \\ ${ }^{2}$ SKCHS, Anantapuramu, Andhra Pradesh, India \\ *Corresponding author
}

\section{A B S T R A C T}

\begin{tabular}{|l|}
\hline Ke y w o r d s \\
Inorganic, Organic, \\
Biofertilizers, \\
Economic analysis, \\
Banana and Grand \\
Naine.
\end{tabular}

\section{Keywords}

Banana and Grand

Article Info

\section{Introduction}

India leads the globe in acreage and production of banana. It is being grown in an area of $0.85 \mathrm{~m}$.ha with an annual production of 30.27 million tonnes (Anon, 2017). Banana, popularly regarded as "Apple of Paradise" is a rich source of vitamins and minerals especially Potassium. Banana owing to its large size and rapid growth rate require relatively large amount of nutrients for higher yield and quality. Application of inorganic fertilizers though increases the yield substantially but could not able to sustain the fertility status of the soil (Somasundaram et al., 2014). Integrated nutrient management (INM) found to be beneficial for maintenance of soil fertility and plant nutrient supply to an optimum level, for sustaining desired crop productivity through optimization of benefits from all possible sources of plant nutrients in an integrated manner. The basic principle of INM is the maintenance of soil fertility, sustainable agricultural productivity and improving farmers' profitability through judicious and efficient use of chemical fertilizers, organic manure, green manure and biofertilizers etc (Bhalerao et al., 2009). Grand Naine is a popular variety grown mostly in all export oriented countries of Asia, South America and Africa. This is a superior selection of Giant Cavendish which 
was introduced to India in 1990's. Due to many desirable traits like excellent fruit quality, immunity to fusarium wilt etc, it has proved better variety (Singh and Chundawat, 2002). Among all cultivars, Grand Naine is best preferred variety owing to its good shape, size and delicious state (Hazarika et al., 2011).

\section{Materials and Methods}

The present investigation was carried out during the years $2012-13$ at College of Horticulture, Anantharajupet which is located at an altitude of 215 meters above mean sea level at $13.98^{\circ}$ North latitude and $79.40^{\circ}$ East longitude, respectively. The maximum and minimum temperatures during the experiment were $39.03^{\circ} \mathrm{C}$ and $31.0^{\circ} \mathrm{C}$ and relative humidity during the period of crop growth ranged between 77.0 to $87.0 \%$ respectively. The experiment consisted of eleven treatments which were replicated thrice and the statistical design used was Randomized Block Design (RBD). The treatments included were $\mathrm{T}_{1}-100 \%$ Recommended dose of fertilizers (RDF) 300:50:300 g NPK plant $^{-1}$ crop cycle ${ }^{-1}, T_{2}-80 \%$ RDF 240:40:240 g NPK plant $^{-1}$ crop cycle $^{-1}$ through inorganic fertilizers $+20 \% \mathrm{RDN}$ through vermicompost (VC), $\mathrm{T}_{3}-80 \% \mathrm{RDF}$ through inorganic fertilizers $+20 \% \mathrm{RDN}$ through $\mathrm{VC}+$ Azospirillum, $\mathrm{T}_{4}-80 \% \mathrm{RDF}$ through inorganic fertilizers $+20 \%$ RDN through VC + Phosphate solubilizing bacteria (PSB), $\mathrm{T}_{5}-80 \%$ RDF through inorganic fertilizers $+20 \%$ RDN through VC + Frateuria aurantia (FA), $\mathrm{T}_{6}-80 \% \mathrm{RDF}$ through inorganic fertilizers $+20 \%$ RDN through VC + Azospirillum $+\mathrm{PSB}+\mathrm{FA}, \mathrm{T}_{7}-$ $80 \%$ RDF through inorganic fertilizers +20 $\%$ RDN (Farmyard manure (FYM), $\mathrm{T}_{8}-80 \%$ RDF through inorganic fertilizers $+20 \%$ RDN (FYM) + Azospirillum, $\mathrm{T}_{9}-80 \% \mathrm{RDF}$ through inorganic fertilizers $+20 \% \mathrm{RDN}$ $(\mathrm{FYM})+\mathrm{PSB}, \mathrm{T}_{10}-80 \% \mathrm{RDF}$ through inorganic fertilizers $+20 \%$ RDN (FYM) + $\mathrm{FA}$ and $\mathrm{T}_{11}-80 \%$ RDF through inorganic fertilizers $+20 \%$ RDN (FYM) + Azospirillum $+\mathrm{PSB}+\mathrm{FA}$.

Calculated quantities of organic manures (Vermicompost @ $0.285 \mathrm{~kg} \mathrm{plant}^{-1}$ and Farmyard manure@5.309 kg plant ${ }^{-1}$ ) along with biofertilizers viz., Azospirillum (50 g), Phosphate solubilizing bacteria $(50 \mathrm{~g})$ and Frateuria aurantia (25 g) were applied directly to the pits prior to planting. The data was analyzed as per the method of variance outlined by Panse and Sukhatme (1985). Statistical significance was tested by $F$ value at $5 \%$ level of significance. Critical difference at 0.05 levels was worked out for the effects which were significant.

Matured bunches were harvested and data on weight of the bunch were estimated as per standard methods. The yield per hectare was calculated by multiplying the average bunch weight with total number of plants per hectare and expressed in tonnes per hectare. The economics of the individual treatment was calculated based on the total cost of cultivation and gross return and were expressed on per hectare basis. The expenditures both recurring and non recurring required during the cropping period were computed based on the investment on preparatory cost including planting materials. Net return was calculated by subtracting gross expenditure from the gross return on per hectare basis. The cost benefit ratio was calculated from the value of total expenditure and gross return based on the benefit obtained on per rupee cost in different treatments separately.

\section{Results and Discussion}

Economics of cultivation is the most important single factor which decides the adoption of any improved practices by the 
grower. The cost - benefit ratio of treatments is another most important factor that determines its usefulness and acceptance by the grower. A treatment should not only be effective but also should be profitable proposition to be acceptance by a grower. In the present study, the different treatments showed clear impact on the comparative economics of the production of banana under the influence of inorganic, organic nutrients in combination with biofertilizers.

\section{Yield analysis}

The yield data pertaining to the banana production under the influence of different combination of organic manures, inorganic nutrients and biofertilizers are given in Table 1. From the data, it is apparent that the treatment $80 \% \mathrm{RDF}$ (inorganic) + $20 \% \mathrm{RDN}$ (FYM) along with Azospirillum, PSB and Frateuria aurantia recorded significantly highest yield (68.02 $\left.\mathrm{t} \mathrm{ha}^{-1}\right)$ compared to other treatments followed by $80 \%$ RDF (inorganic) $+20 \%$ RDN (vermicompost) along with Azospirillum, PSB and Frateuria aurantia $\left(66.31 \mathrm{t} \mathrm{ha}^{-1}\right)$. Lowest yield $\left(53.65 \mathrm{t} \mathrm{ha}^{-1}\right)$ was recorded by $100 \%$ RDF (inorganic).

\section{Total cost of cultivation}

Among all the treatments, highest cost of cultivation $86,280.13 \mathrm{Rs} /-\mathrm{ha}^{-1}$ was incurred in $80 \% \mathrm{RDF}$ (inorganic) + $20 \% \mathrm{RDN}$ (vermicompost) along with Azospirillum, PSB and Frateuria aurantia followed by 84, 877.43 Rs $/-$ ha $^{-1}$ in $80 \%$ RDF (inorganic) + $20 \%$ RDN (FYM) along with PSB and lowest of 78, $509.95 \mathrm{Rs}^{-}-\mathrm{ha}^{-1}$ in $100 \% \mathrm{RDF}$ (inorganic).

\section{Gross return}

INM package with $80 \%$ RDF (inorganic) + $20 \%$ RDN (FYM) along with Azospirillum, PSB and Frateuria aurantia recorded highest gross returns in monetary terms $(3,74,110 \mathrm{Rs}$ /-) followed by $80 \% \mathrm{RDF}$ (inorganic) $+20 \%$ RDN (vermicompost) along with Azospirillum, PSB and Frateuria aurantia (3, 64, 705 Rs /-) and the lowest (2, 95, $075 \mathrm{Rs})$ was in $100 \% \mathrm{RDF}$ (inorganic).

Table.1 Economics of the banana cv. Grand Naine (AAA) cultivation as influenced by different INM treatments

\begin{tabular}{|l|c|c|c|c|c|}
\hline \multicolumn{1}{|c|}{ Treatments } & $\begin{array}{c}\text { Yield } \\
\left(\mathbf{t ~ h a}^{-\mathbf{1}}\right)\end{array}$ & $\begin{array}{c}\text { Total cost of } \\
\text { cultivation }\end{array}$ & Gross returns & Net returns & $\begin{array}{c}\text { Benefit : Cost } \\
\text { ratio }\end{array}$ \\
\hline $\mathbf{T}_{\mathbf{1}}: 100 \%$ RDF & 53.65 & 78509.95 & 295075 & 216565.05 & 2.76 \\
\hline $\begin{array}{l}\mathbf{T}_{\mathbf{2}}: 80 \% \text { RDF + 20\% } \\
\text { RDN through VC }\end{array}$ & 54.89 & 83895.33 & 301895 & 217999.67 & 2.60 \\
\hline $\mathbf{T}_{\mathbf{3}}: \mathrm{T}_{2}+$ Azospirillum & 57.97 & 84877.43 & 318835 & 233957.57 & 2.76 \\
\hline $\mathbf{T}_{\mathbf{4}}: \mathrm{T}_{2}+$ PSB & 60.99 & 84877.43 & 334950 & 250072.57 & 2.95 \\
\hline $\mathbf{T}_{\mathbf{5}}: \mathrm{T}_{2}+\mathrm{FA}$ & 65.15 & 84315.93 & 358325 & 274009.07 & 3.25 \\
\hline $\begin{array}{l}\mathbf{T}_{\mathbf{6}}: \mathrm{T}_{2}+\text { Azospirillum + } \\
\text { PSB + FA }\end{array}$ & 66.31 & 86280.13 & 364705 & 278424.87 & 3.23 \\
\hline $\begin{array}{l}\mathbf{T}_{\mathbf{7}}: 80 \% \text { RDF + 20\% } \\
\text { RDN through + FYM }\end{array}$ & 59.61 & 79075.52 & 327855 & 248779.48 & 3.15 \\
\hline $\mathbf{T}_{\mathbf{8}}: \mathrm{T}_{7}+$ Azospirillum & 56.57 & 80057.62 & 311135 & 231077.38 & 2.89 \\
\hline $\mathbf{T}_{\mathbf{9}}: \mathrm{T}_{7}+$ PSB & 54.76 & 80057.62 & 301180 & 221122.38 & 2.76 \\
\hline $\mathbf{T}_{\mathbf{1 0}}: \mathrm{T}_{7}+$ FA & 59.36 & 79496.12 & 326480 & 246983.88 & 3.11 \\
\hline $\begin{array}{l}\mathbf{T}_{\mathbf{1 1}}: \mathrm{T}_{7}+\text { Azospirillum + } \\
\text { PSB + FA }\end{array}$ & 68.02 & 81460.32 & 374110 & 292649.68 & 3.59 \\
\hline
\end{tabular}

RDF: Recommended dose of fertilizers, RDN: Recommended dose of nitrogen, PSB: Phosphate solubilizing bacteria, FA: Frateuria aurantia 
Table. 2 Cost of cultivation of Tissue Culture banana cv. Grand Naine (AAA) per hectare

\begin{tabular}{|c|c|c|}
\hline S. No. & Particulars & Cost ha $^{-1}(\mathrm{Rs} /-)$ \\
\hline 1 & Land preparation (Deep ploughing and harrowing) & $10,000.00$ \\
\hline 2 & Preparation of channels & $2,210.00$ \\
\hline 3 & Digging pits & $6,500.00$ \\
\hline 4 & Cost of fertilizer treatments wise per hectare & \\
\hline 4.1 & $100 \% \mathrm{RDF}$ & $3,169.95$ \\
\hline 4.2 & $80 \%$ RDF (Inorganic) + 20\% RDF Vermicompost (VC) & $8,555.33$ \\
\hline 4.3 & $80 \%$ RDF (Inorganic) + 20\% RDF (VC) + Azosprillum & $9,537.43$ \\
\hline 4.4 & $\begin{array}{c}80 \% \text { RDF (Inorganic) + 20\% RDF (VC) + Phosphorus } \\
\text { solubilizing bacteria (PSB) }\end{array}$ & $9,537.43$ \\
\hline 4.5 & $\begin{array}{c}80 \% \text { RDF (Inorganic) + } 20 \% \text { RDF (VC) + Frateuria } \\
\text { aurantia (FA) }\end{array}$ & $8,975.93$ \\
\hline 4.6 & $\begin{array}{c}80 \% \text { RDF (Inorganic) }+20 \% \text { RDF (VC) + Azosprillum } \\
+ \text { PSB + FA }\end{array}$ & $10,940.13$ \\
\hline 4.7 & $80 \%$ RDF (Inorganic) $+20 \%$ RDF (FYM) & $3,735.52$ \\
\hline 4.8 & $\begin{array}{c}\text { 80\% RDF (Inorganic) + 20\% RDF (FYM) + } \\
\text { Azosprillum }\end{array}$ & $4,717.62$ \\
\hline 4.9 & $80 \%$ RDF (Inorganic) + 20\% RDF (FYM) + PSB & $4,717.62$ \\
\hline 4.10 & $80 \%$ RDF (Inorganic) + 20\% RDF (FYM) + FA & $4,156.12$ \\
\hline 4.11 & $\begin{array}{c}80 \% \text { RDF (Inorganic) + 20\% RDF (FYM) + } \\
\text { Azosprillum + PSB + FA }\end{array}$ & $6,120.32$ \\
\hline 5 & Irrigation & $7,540.00$ \\
\hline 6 & Weeding & $13,200.00$ \\
\hline 7 & Fertilizer application & $16,800.00$ \\
\hline 8 & Planting material & $5,280.00$ \\
\hline 9 & Planting & $2,040.00$ \\
\hline 10 & Labour cost for spraying chemicals & $3,770.00$ \\
\hline 11 & Plant protection chemicals & $3,000.00$ \\
\hline 12 & Harvesting and loading & $5,000.00$ \\
\hline
\end{tabular}

\section{Net return}

The net return is the main parameter for deciding the adoptability of a farming system. The highest net income of 2, 92, $649.68 \mathrm{Rs} /-$ $\mathrm{ha}^{-1}$ was obtained with $80 \%$ RDF (inorganic) + $20 \%$ RDN (FYM) along with Azospirillum, PSB and Frateuria aurantia followed by 2, 78, 424.87 Rs /- ha $^{-1}$ under $80 \%$ RDF (inorganic) + $20 \%$ RDN (vermicompost) along with Azospirillum, PSB and Frateuria aurantia. The lowest net income of 2, 16, $565.05 \mathrm{Rs} /-\mathrm{ha}^{-1}$ was recorded in $100 \% \mathrm{RDF}$ (inorganic).
Benefit - cost analysis

The evaluation of relative merit of integration of inorganic fertilizers and organic manures concomitant with biofertilizers in the present study in augmenting yield and thereby income. The data presented in Table 1 revealed that maximum cost benefit ratio of $3.59: 1$ was obtained in $80 \%$ RDF (inorganic) $+20 \%$ RDN (FYM) along with Azospirillum, PSB and Frateuria aurantia, followed by $3.25: 1$ in $80 \%$ RDF (inorganic) $+20 \%$ RDN (vermicompost) along with Frateuria aurantia. The highest ratio in $80 \%$ RDF (inorganic) + $20 \% \mathrm{RDN}$ (FYM) 
along with Azospirillum, PSB and Frateuria aurantia might be due to the comparatively higher yield of $68.02 \mathrm{t} \mathrm{ha}^{-1}$ which ultimately increases the cost benefit ratio. Among all the treatments, the lowest cost benefit ratio of 2.60: 1 was obtained in $80 \%$ RDF (inorganic) $+20 \%$ $\mathrm{RDF}$ (vermicompost) which was mainly due to high gross expenditure with comparatively lower yield $\left(54.89 \mathrm{t} \mathrm{ha}^{-1}\right)$.

Economic benefit of any farming system is the major factor for its adoption by farmers. Different studies conducted in various parts of the globe proved that INM packages are superior to any other fertilizer management in respect of economics of cultivation in different crops. Marathe and Bharambe (2007) obtained complete supremacy in treatment using INM packages with $50 \% \mathrm{RDF}+50 \% \mathrm{FYM}$ over the inorganic fertilizers with a highest cost benefit ratio of 4.59 in sweet orange cv. Mosambi. Our study is in the line of conformity with the findings of Chundawat et al., (1983), Borges et al., (1994), Kulkarni et al., (1996), Duraiswami et al., (1999) and El Naby (2000), who reported different INM packages including inorganic fertilizers, organic manures concomitant with biofertilizers in getting the maximum returns per unit as compared to the inorganic fertilizers alone.

\section{References}

Anonymous. 2017. $3^{\text {rd }}$ Advance Estimate. National Horticulture Board. Pp -6 .

Bhalerao, V.P., Patil, N.M, Badgujar, C.D. and Patil, D.R. 2009. Studies on Integrated Nutrient Management for tissue culture Grand Naine banana. Indian Journal of Agriculture Research. 43(2): 107-112.
Borges, A.L. 1994. Liming and fertilizing banana. CNPMF Report (Musa Doc. 1999). Pp.2.

Chundawat, B.S, Dave, S.K. and Patil, N.L. 1983. Effect of sources of nitrogen on yield and economics of banana cv. Basrai. Haryana Journal of Horticultural Science. 12: 156-159.

Duraiswamy, R, Mani, A.K. and Balasubramaniam, P. 1999. Effect of fertilizer nitrogen, Azospirillum and organics on yield and nutrition of rainfed tomato. South Indian Horticulture. 47: 234-236.

El-Naby S.K.M.A. 2000. Effect of banana compost as organic on growth, nutrient status, yield and fruit quality of Maghrabi banana. Assiut Journal of Agricultural Science. 31: 101-104.

Hazarika, T.K., Nautiyal, B.P. and Bhattacharya. R.K. 2011. Effect of INM on productivity and soil characteristics of tissue cultured banana cv. Grand Naine in Mizoram, India. Progressive Horticulture. 43: 30-35.

Kulkarni, B.S, Nalwadi, U.G. and Giraddi, R.S. 1996. Effect of vermicompost and vermiculture on growth and yield of China aster (Callistephus chinensis Nees) cv. Ortrich Plume Mised. South Indian Horticulture. 44: 33-35.

Marathe, R.A. and Bharambe, P.R. 2007. Growth, yield and quality of sweet orange cv. Mosambi in response to INM in vertisols of central India. Indian Journal of Horticulture. 64: 274277.

Panse, V.G. and Sukhatme, P.V. 1985. Statistical Methods for Agricultural Workers. ICAR, New Delhi.

Singh, H.P. and Chundawat, B.S. 2002. Improved Technology of Banana. Ministry of Agriculture, Government of India. Pp 1-46.

Somasundaram, E, Kuttimani, R. and Velayudham. K. 2014. Proceedings of the $4^{\text {th }}$ ISOFAR Scientific Conference. 'Building Organic Bridges', at the Organic World Congress 2014, 13 - 15 Oct., Istanbul, Turkey.

\section{How to cite this article:}

Firoz Hussain, S., Lakshminarayana Reddy and Venkata Ramudu. 2017. Conjunction of Inorganic and Organic Nutrients in Combination with Biofertilizers on Economic Analysis of Tissue Culture Banana cv. Grand Naine (AAA). Int.J.Curr.Microbiol.App.Sci. 6(12): 3823-3827.

doi: https://doi.org/10.20546/ijcmas.2017.612.440 